\title{
ストレスの生命科学 \\ Life Science of Human Stress
}

\begin{tabular}{|c|c|}
\hline $\begin{array}{r}\text { 二木鋭雄 } \\
\text { 宇都宮大学 } \\
\text { 工学部応用化学科 } \\
\text { ₹ 321-8585 } \\
\text { 栃木県宇都宮市陽東 7-1-2 }\end{array}$ & $\begin{array}{l}\text { 野口範子 } \\
\text { 東京大学 先端科学技術研究センター } \\
\text { ₹ 153-8904 } \\
\text { 東京都目黒区駒場 4-6-1 }\end{array}$ \\
\hline $\begin{array}{r}\text { Etsuo NIKI } \\
\text { Utsunomiya University, Department } \\
\text { of Applied Chemistry } \\
7-1-2 \text { Yoto, Utsunomiya 321-8585 }\end{array}$ & $\begin{array}{l}\text { Noriko NOGUCHI } \\
\text { University of Tokyo, Research Center } \\
\text { for Advanced Science and } \\
\text { Technology } \\
4-6-1 \text { Komaba, Meguro, Tokyo } 153-8904\end{array}$ \\
\hline
\end{tabular}

\begin{abstract}
Today, we are always exposed to stress. Versatile chemical, biological, physical and social stress attack us. On the other hand, stress is a double-edged sword and some of the stress exert beneficial effect. In order to protect us from the stress to maintain good health and high quality of life, it is essential to clarify and understand the mechanisms of biological responses to the stress, to assess the extent of stress, and to establish ways to cope with such stress. The life science of stress including the role of oleoscience will be one of the most important future subjects.
\end{abstract}

Key words: Stress, Oxidative Stress, Life Science, Quality of Life

\section{1 はじめに}

いま，われわれのまわりにはストレスがあふれてい る。ストレスとは元来物理学の用語で, ある刺激に対し て生ずる歪み，ゆがみのことを意味した。たとえば，ゴ ム球に力をかけるとへこむが，このへこみをストレスと 言う。生体に対するストレスとは，生体に加えられた刺 激であり，それによって生ずる生体の応答，傷害，防御 も広い意味で含まれる。ストレスを引き起こす刺激をス トレッサー, stressor と名づけられたが，現実にはこれ もストレスと厳重な区別がされずに使われている。スト レッサーをストレス刺激，ストレスをストレス反応と区 別して言うこともある。結局,「外界からのあらゆる刺 激に対する生体の非特異的な反応」がストレスであり, 「ストレスを生じさせるもの」がストレッサーと定義さ れる。

生物に対するストレスに関する科学的な研究は, カナ ダのセリエ教授(Hans Selye, 1907-1982)によってはじめ てなされた。セリエは論文「ネズミの母体内胎盤の生理 学的研究」の中で, ストレスという言葉をはじめて用い た。セリエは隇食による飢餓から生ずるストレスに加え

連絡者 : 二木 鋭雄

住 所： $\mathbf{7} 563-8577$ 大阪府池田市緑丘 1-8-31 ヒューマンストレスシグナル研究センター
て, ビタミン D や E の欠乏, 出血, 強制的な筋肉運動, さらには寒冷や暑熱, 激しい音や光, ホルムアルデヒド のような化学物質, などなど多種のストレスの影響を調 べた。そして, ストレスの種類が多種, 多様と異なって も, 共通の症状が認められることを見出した。その症状 とは, 副腎皮質の肥大, 胸腺とリンパ腺の縮小, そして 胃や十二指腸の潰瘍の生成であった。このようなストレ ス刺激が加わったときに起こる生体の反応をセリエは 「全身適応症候群」と呼んだ。

現代社会に生きるわれわれは, 正に多種多様なストレ スに常にさらされている。ストレスがどのように生体に 影響を及ぼし, 生体がどう応答するのか, どのような傷 害が生じるのか, これらを科学的に解明し, 測定, 検出 すること, そしてそれを克服する人間工学を発展させる ことが, 特に高齢化が進むいま, 高い生活の質 (Quality of Life)を実現するためにも必要なことと思われる。

\section{2 ストレスの種類}

ストレスには, Fig.1に示したように，化学的ストレ ス，生物的ストレス，物理的ストレス，さらには社会的 なストレスと, 非常に多様なものがある。これらを厳密 に一つの特定のカテゴリーに分類することは容易でない

し，またその必要もない。

化学的ストレスとして, まず種々の化学物質があげら 


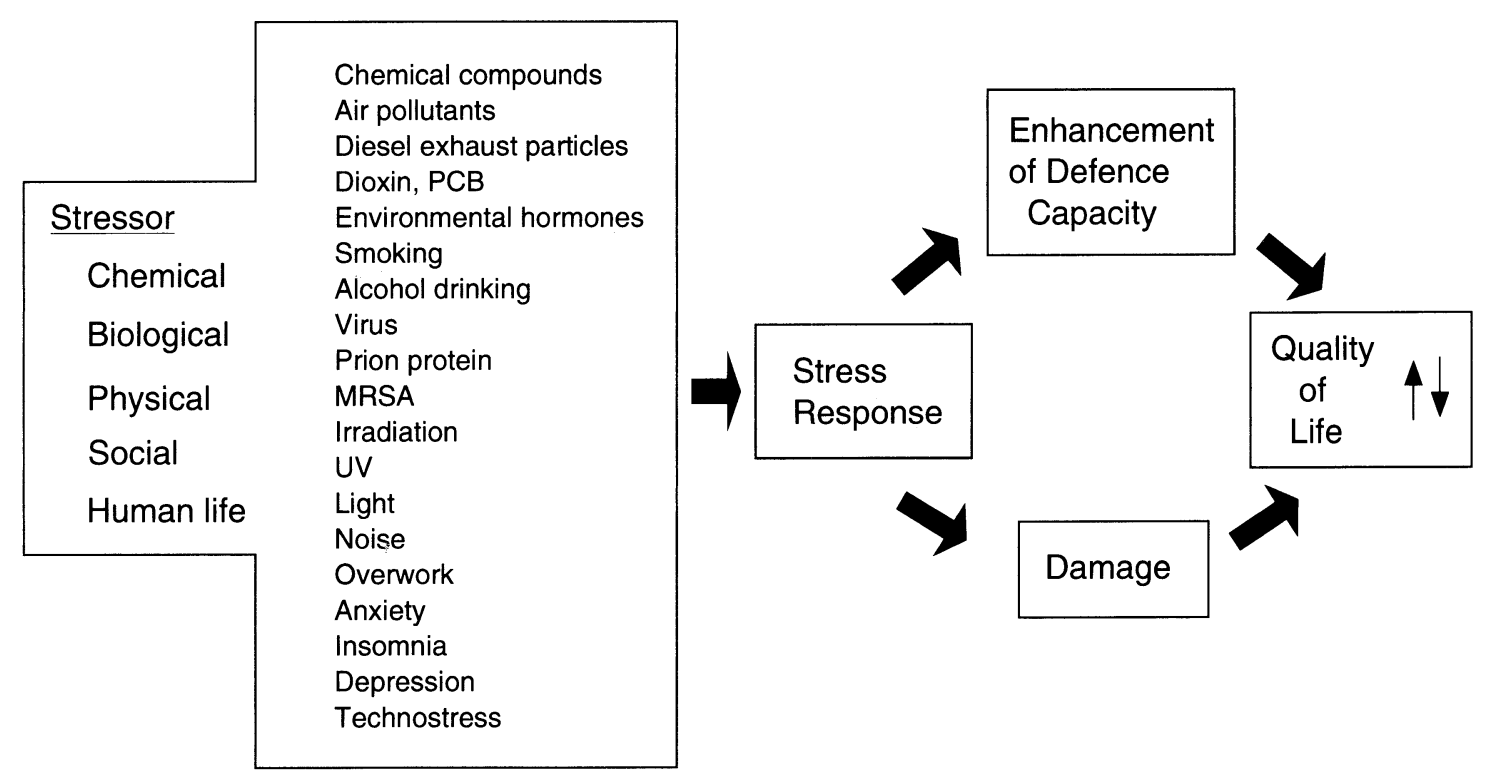

Fig. 1 Stressor and Response

れる。カドミウム, クロム, 有機水銀化合物のような金 属の生体に対する毒性はよく知られている。ホルムアル デヒドは今から 65 年も前にセリエによって試験された 化合物であるが, いま, シックハウス症候群との関連で 注目されている。PCB, DDT, ダイオキシンなどの含 塩素化合物もその強い毒性が知られている。薬物の副作 用も例の一つと言えよう。現在, 新規化学物質は確実に 増えつづけており，これらが生体にどのようなストレス を与えるのか, ほとんど分かっていないのが現状であ る。

その他, 高酸素, 低酸素, 栄養不足, なども化学的ス トレスと言える。高濃度の酸素下で飼育すると動物の寿 命が短くなることが認められている。

物理的ストレスとして，低温と高温，放射線や紫外 線, その他騒音や振動などもある。フロンガスという新 規含ハロゲン化合物が開発され，広く利用されたが，そ れが成層圈のオゾンを分解してオゾンホールをもたら し，そのため地上に到達する紫外線強度の増加という物 理的ストレスの増加を招いていることも周知のことであ る。紫外線強度と皮膚がん発症とが相関することが認め られている。

生物的ストレスとしては, 病原菌，ウイルスなどが代 表的なものである。最近院内感染の原因として問題に なっている MRSA (メチシリン耐性黄色ブドウ球菌) も その例の一つである。プリオンは最近狂牛病との関連で 話題になった。

社会的ストレスは複雑で, 近代社会で特により重要と なってきていると考えられる。自然災害や事故のような 極度に強いストレスによる傷害である PTSD (Post Trau- matic Stress Disorder，心的外傷後ストレス症候群)が知 られている。しかし，人間関係，仕事，過労，不眠など から生ずる日常的なストレスの影響が一般の人にとって はより大きく切実と考えられる。心理的ストレス刺激を 受けると情動変化を起こし，身体的ストレス反応の引金 となる。テクノストレスもコンピューター社会となった 現代社会の産物といえよう。

これらストレスがどのような機序で生体に影響を及ぼ してるのか，その詳細は謎である。しかし，先にも述べ たように，一見全く異なる多種多様なストレスが共通の 症状を引き起こすということは，何か共通のシグナル， メカニズムがあるのではないかと推測させる。

\section{3 酸化ストレス}

酸化力を有する活性種による刺激によって生ずる傷 害，いわゆる酸化ストレスに関する研究はここ 20 年間 に精力的に研究が行なわれ，かなりのことが理解される ようになってきている。酸化力が，それを防ごうとする 抗酸化力を上まわるときを酸化ストレスであるとする考 え方もあるが，抗酸化力を上まわることのない酸化スト レスもやはりストレスであることに変わりはない。これ は生体の反応を考えるとき，決定的に重要なことであ る。酸化力が抗酸化力を上まわると，傷害となってあら われることになる。

酸化ストレスとして古くから知られているものに放射 線障害がある。東海村事故の記憶も新しい。放射線の照 射により腫瘍の生成，寿命の短縮がおこることが知られ ているが，この傷害が酸素の存在下では増幅されること が認められている。この場合に，ヒドロキシルラジカル 
などのフリーラジカルが生成し，これが傷害をひき起こ すことが知られているが，その後の多くの研究により， 種々の酸素ラジカルや活性酸素種が生体に傷害をもたら すことが明らかになってきた。

酸化ストレスが生体に対して傷害を与えるということ を支持するものとして, 抗酸化物のストレス防御効果が ある。すなわち, 酸化ストレスが傷害の原因となるなら ば，それを抑えることにより傷害が抑制，予防されると いうことになるが，実際，そのような抗酸化物の効果が 認められているということである。

in vitro の研究により, 生体を構成する脂質, 蛋白質, 核酸が活性酸素種, 活性窒素種やラジカルによる攻撃を 受けて酸化され，それにより生体膜脂質が酸化され過酸 化物およびその二次酸化物を生ずること, 蛋白質が変性 し，切断，架橋反応を起こすこと，それにより酵素の不 活性化につながること，核酸の塩基の修飾，また主鎖の 切断がおこること，などが明らかになってきている。in vitro のモデル系ではあるが，生体分子の酸化反応の理 解はかなり進んできている。

動物実験でも数多くの知見が得られている。高濃度酸 素による下等動物の寿命短縮, 酸素消費速度と寿命の逆 相関，抗酸化酵素の過剩発現による寿命の延長，など多 くの実験結果が報告されている。

セリエは 65 年前にネズミを使って多くの実験を行 なったが，最近でもネズミを用いた研究例が多い。ネズ ミをかごの中に拘束して水に近づけると，大きなストレ スを感じ(と思われる)，胃潰瘍になる。このとき，活性 酸素種の生成や抗酸化物による抑制が確認されている。 すなわち，スーパーオキサイドが生成すること，および それを消去する抗酸化酵素であるスーパーオキシドディ スムターゼ (SOD)や，ペルオキシルラジカルを捕捉する ビタミン Eが胃潰瘍の発症を抑えることが, 実験的に確 認されている。これらは，この水浸拘束ストレスによる 胃潰瘍発生が酸化ストレスによるものであることを示し ている。ストレス性胃潰瘍は近代社会の典型的な産物の 一つと言えよう。

われわれは, 熱的な一分子分解によってフリーラジカ ルを発生するアゾ化合物を用いて種々の研究を続けてい る。たとえば水溶性アゾ化合物である，2,2-azobis(2-amidinopropane) dihydrochloride (AAPH と略す)が 脂質, 蛋白質の酸化, リポ蛋白質の酸化変性, 赤血球の 酸化的溶血, 細胞死 (ネクローシス, アポトーシスとも に）誘発することをin vitro および ex vivo の系で確認 した。また，マウスを用いた動物実験で，リンパ腺や内 皮細胞の傷害および肝障害を引き起こすことを確認して いる。これらについても, 抗酸化物の抑制効果を確認し
ており，酸化ストレスによるものと言える。AAPHを 用いた実験はその後各国で行なわれている。

心筇梗塞や脳梗塞の原因となる動脈硬化をはじめ, 糖 尿病, 白内障, リュウマチ性関節炎, あるいはパーキン ソン病など痴呆発症に，酸化ストレスが梁く関わってい ることが次第に明らかになってきている。加齢もまたス トレスの一つとして考えられているが，社会の高齢化と ともにこれら老年病，生活習慣病はこれからますますそ の重要性が大きくなるであろうことは間違いない。

\section{4 善玉としてのストレス}

酸素，あるいは抗酸化物に二面性があるように，スト レスも両刃の剣であることが分かっている。生物には， 恒常性 (homeostasis, ホメオスタシス) という適応力が ある。すなわち, ある刺激に対して, 常に一定の状態で あろうとする適応力がある。たとえば，われわれの体温 は, 夏の盛りでも真冬でも, 健康であるかぎり, 36 度 から 37 度の間に，ほほ一定に保たれている。これは恒 常性を示すよい例である。

このように生体は, 外からのストレスに対して適応し ようとする。たとえば，酸化ストレスがかかると，それ に対抗，適応するために，抗酸化力を高めようとするこ とが認められている。放射線のストレスについてはすで に述べたが，低線量の放射線を照射すると, SOD, グル タチオンペルオキシターゼなどの抗酸化酵素が産生し, 一過性にストレスに対する防御力が増加することが知ら れており，これをホルミシス効果と呼んでいる。このた め, あらかじめ低線量の放射線を照射してから，より大 きな量の放射線を照射すると, 生ずる傷害が低減するこ とが実験的に確認されている。すなわち, 適度なストレ スはむしろ好結果をもたらす善玉である, ということに なる。

低線量の放射線照射が免疫機能の昂進にもつながるこ とも報告されている。健常なラットに 0.15 グレイ程度の 低い線量の X 線を全身照射すると脾臓のリンパ球の幼 若化反応が高まること, あるいは低線量照射された胆ガ ンマウスで, 免疫機能を活性化させるインターロイキン -6(IL-6)の産生と, ガン細胞に壊死効果をもたらす腫瘍 壊死因子 $-a(\mathrm{TNF}-a)$ の産生が高まることも認められて いる。これらのことも, 適切なストレス, 刺激が生体に とって好ましいものであることを示している。

非致死量のストレスを細胞に与えると，多くの蛋白質 は合成が低下するが，ある種の蛋白質の合成が誘導され るようになる。これをストレス蛋白質という。熱ショッ ク蛋白質 (HSP, heat shock protein)はその例の一つで ある。非致死的熱処理を前もって加えられた細胞は, そ 
の後致死的熱処理に対して耐性を獲得する。これは HSP が生体防御機構の一つとして働いていることを示してい る。

\section{5 ストレスに対する生体の応答}

生物, 特に高等生物は, 何億年という長い進化の過程 において，ストレスに対する種々の適応機能を身につけ てきたと考えられる。最初，嫌気的雲囲気下のこの地球 上で誕生した原始生命が，大気中の酸素濃度の上昇によ り，元来毒であった酸素を利用するようになったことは 正に革命的なことであった。酸素およびそれに由来する 活性酸素種により生ずるストレスに対する適応戦略を構 築することによりはじめて酸素を利用することが可能と なったと想像される。好気性生物にとって，酸化ストレ スは最も大きなストレスと考えられる。

活性酸素やフリーラジカルが酸化傷害を誘発し，広範 な疾患に関わることが明らかにされてきたが，これらの 逆の，善玉としての作用についても近年注目されてい る。病原微生物や異物に対するマクロファージ，好中 球，あるいはリンパ球の生体防御機能の発現で活性酸素 が重要な働きをすることはよく知られていたが，近年， 活性酸素種, 一酸化窒素, 他のフリーラジカルが細胞内 情報伝達分子メッセンジャーとして, 種々の細胞応答, 遺伝子発現，ストレス蛋白質発現の制御にも関与するも のとして注目されている。嫌気性菌である大腸菌でも， 酸素に曝すと $\mathrm{Mn}-\mathrm{SOD}$ ，カタラーゼ, ペルオキシダー ゼの合成が誘導されることが認められている。酸化スト レスにより誘導されるストレス蛋白質として，先に述べ た熱ショック蛋白質に加えて，へムオキシゲナーゼ (HO-1)がよく知られている。へムオキシゲナーゼはへ ムを基質とし，ビリベルジン，鉄および一酸化炭素を産 生する酵素である。HO-1 はカドミウム，セレン，亜ヒ 酸などの金属により転写レベルで誘導される。低酸素に より誘導されるエリスロポイエチンも，金属ポルフィリ ンによっても誘導される。低酸素に応答して発現制御す る因子の一つとして HIF-1 (hypoxia inducible factor-1) も見出されている。ストレス蛋白質の一つであるチオレ ドキシンが，還元酵素としてだけではなく，シグナル伝 達系で重要な役割を果たしているという報告もある。

メ夕ロチオネインは分子量約 6000 の低分子量蛋白質 であるが，重金属，放射線などのストレスによりその生 合成が誘導される。このメタロチオネインを上昇させた 培養細胞や動物が，カドミウムや水銀などの重金属ある いは放射線や紫外線などに対して抵抗性を示すことが認 められている。放射線照射から引き起こす骨髄傷害もメ タロチオネイン合成剤の前投与により著明に軽減される
ことが報告されている。

細胞死はネクローシス (necrosis) とアポトーシス (apoptosis）に分類されている。前者は強いストレス刺激によ り細胞が対応できず死ぬ細胞死である。一方，後者はプ ログラムされた細胞死 programmed cell death とも言わ れ，特に発生学でよく認められているものである。たと えば，手指の水掻き様被膜の細胞死による手指の形成， オタマジャクシの尻尾の脱落, 臓器の大きさの決定, な どに重要な働きをする。アポトーシスはあらかじめ細胞 内でプログラムされているようであるが，非生理的なス トレス刺激によっても起こすことができる。例えば，先 に述べた AAPH によってアポトーシスが起こることを 認めている。腫瘍壊死因子(TNF) はある種のがん細胞の アポトーシスを起こすことが知られている。TNFによ るアポトーシスは，熱処理というストレス刺激で促進さ れる。すなわち，あるストレス刺激の前処理により，別 のストレス刺激に対して促進されることもあれば，耐性 を示すこともある。まだ詳細なメカニズムは解明されて いないが，これらをうまくコントロールすることが可能 になれば，その意義は大きい。

活性酸素，フリーラジカル，酸化ストレスによる $\mathrm{NF}-\kappa \mathrm{B}$ (nuclear factor kappa B) や AP-1 (activator protein-1)などの転写調節因子の活性化と遺伝子発現調節, 癌抑制遺伝子 p 53 やアポトーシス抑制遺伝子 bcl-2 の発 現調節などの生理的意味，寄与が近い将来明らかになる ことが期待される。

免疫とストレスとの関連も興味深い。ストレスにより 免疫能が低下することが認められている。その結果, 感 染に対する防御力の低下を招き，それが，例えば，ガン の発症, 進行促進にもつながると考えられる。一方逆 に，ストレスにより副腎皮質からのアドレナリンの放出 がおこり，免疫能が増強されることもある。現代の文明 病と言われる花粉症やアトピー性皮膚炎などとの関連で 重要な課題である。

シックハウス症の原因ともなる化学物質過敏症の機序 もほとんど分かっていない。ホルムアルデヒド，トルエ ン，キシレン，可塑剤などに生体がどう応答するのか， 基礎科学的アプローチによる研究が必要であろう。

\section{6 ストレスの検出, 測定}

種々のストレス刺激により傷害が生じ，それが障害， 疾病につながることがあることを述べてきた。生体内の どこで，どのような傷害が生じているのかを，できるだ け早く検出することが，障害を防ぎ，疾病を予防する， あるいは治療するために必要である。たとえば，ディー ゼル排気ガスやダイオキシンによる発癌, 精神的ストレ 
スによる胃潰瘍, 不安感による不眠など, これらを如何 に早い段階で見出し，それを防ぐことができるか，とい うことである。そのためには, 高感度で特異的な検出手 段を開発する技術が欠かせない。ヒトを対象とする場 合, 非侵襲的に, 要するに体を傷つけずに, 測定するこ とも要求される。同時に，何を測定すれば正しく評価で きるのか, そのマーカーを見出すことも必要である。破 綻が起こる前にそれを察知し，防ぐことが重要であり， そのためにもストレスマーカーの同定, 検出, 定量化が 大切である。そのためには，そのストレスによる生体の 応答, 傷害の発生メカニズムなどを理解することが不可 欠である。近年, 高感度の分析機器や抗体を用いたイム ノアッセイなど，すぐれた方法が開発されているが，根 本の基礎科学の研究の方が遅れ，まだまだ未解明の問題 が多いように見受けられる。地道な基礎研究への取り組 みが望まれる。

ヒトが不安, おどろき, 怒り, 過労などのストレスを 受け，感じたとき，生理状態がどう変化するのか，心 拍, 呼吸, 体温, 発汗などを測定し, 解析することも重 要であろう。

\section{7 オレオサイエンスの役割}

さて, このストレスの生命科学において, オレオサイ エンスの位置づけはどうであろうか。近年の研究の結果 の一つとして, 食事や栄養の健康, 加齢に対する重要性 がますます明らかになってきている。基質としての脂 質, 微量栄養素としてのビタミン, 金属など, ヒトが質 の高い生活を送るために極めて重要であることが認識さ れてきている。 $\mathrm{n}-3, \mathrm{n}-6$ 脂肪酸の生理的影響の差など, まだ解明されていない課題も多い。ストレスが加わる と, 脂肪組織から遊離脂肪酸の産生が促進され，アセチ ルコエンザイム A となってコレステロールの増加を招 くなど，脂質代謝に影響を及ぼすことが認められてい る。

日本の三大死因はガン, 心疾患, 脳血管障害である が，後者の二つは動脈硬化と深く関わっている。この動 脈硬化の進展にストレスが影響すると言われている。な かでも酸化ストレスが引き金となるという説は広く受け 入れられている。低比重リポタンパク質 (Low Density Lipoprotein, LDL) が酸化変性を受けると, マクロファー ジに際限なくとりこまれるようになり，血管壁の内側で 泡沫細胞となってコレステロールなどが沈着し, 動脈壁
が厚くなる。さらに，ストレスが加わると，交感神経の 働きが活発化し, 副腎髄質からカテコールアミンやレニ ン，アンジオテンシンなどの分泌が盛んになり，血圧や 心拍数を増加させ，そして下垂体から成長ホルモンや副 腎皮質刺激ホルモンの分泌が高まる。これらの一連の流 れによって，脂質の代謝が活発になり，血行動態が悪く なる。結局，ストレスによって心臓の拍出量の増加，末 梢血管の収縮，血小板の凝集能増加，血小板由来増殖因 子 (PDGF)の分泌促進などが引きおこされ, 動脈硬化を 促進するという結果になる。

セレンなど微量金属イオンの作用も興味深い。ビ夕ミ ン D，Eなどについて，これまで知られていた生理作用 を越える新しい，別の作用も明らかになりつつある。 DNA チップを用いた研究も進みつつあり，分子，遺伝 子，蛋白質レベルでの解明が期待される。一方，社会生 活や精神的ストレスに対する化粧などの緩和作用も，別 の観点から興味深いテーマである。

\section{8 これからの展望}

あらゆる意味でストレス刺激が質，量ともにふえつつ ある現代，それに対して生体がどう応答し，生活にどう 影響するかについて正面から取り組み，解明することの 意義は極めて大きい。一見，全く様相を異にするストレ スも，生体およびそれを構成する細胞へのシグナルであ るととらえ，それに対する生体の応答，傷害の検出，予 防と治療を研究するストレスバイオサイエンスは，これ からの重要な研究課題であるばかりでなく, 日々の生活 に密着したことであり, 生命科学産業の一つの重要な分 野となることは間違いない。

\section{文献}

1）平野鉄雄, 新島旭著, (1995）脳とストレス, 共立出 版.

2) 井上正康編, (1996) 活性酸素とシグナル伝達, 講談社 サイエンティフィック.

3）ハンス・セリエ著，（1997）生命とストレス，細谷東一 郎訳, 工作舎.

4）森本兼暴著,（1997）ストレス危機の予防医学, 日本放 送出版協会.

5）谷口直之, 淀井淳司編，（2000）酸化ストレスとレドッ クスの生化学, 共立出版.

6）森本兼景, (2000) 現代医学々社会, 井村裕夫, 高久史 麿編集, 岩波講座現代医学の基礎 15 , 第 4 章, p.49, 岩波書店 


\title{
論 文 要 旨
}

\section{綴説 ストレスの生命科学}

\author{
二木鋭雄 $\mathrm{a} \cdot$ 野口範子 $^{\mathrm{b}}$
}

a 宇都宮大学 工学部応用化学科（T321-8585 栃木県宇都宮市陽東 7-1-2）

b 東京大学 先端科学技術研究センター（T153-8904 東京都目黒区駒場 4-6-1）

現代はストレスの時代と言われている。化学的, 生物的, 物理的ならびに社会, 人間生活的な多種多様なストレス にわれわれは常にさらされている。一方，ストレスも両刃の剣であり，生体にとって罒いストレス（Distress）に加え， 良いストレス（Eustress）もある。これらストレスから自らを守り，あるいはそれを利用して，より健康で質の高い生 活を送るためにも, ストレスに対する生体の応答メカニズムを科学的に正しく解明, 理解すること, ストレスの負荷 を検出，測定すること，そしてそれに対処する方策を見出すことが重要である。オレオサイエンスの役割も含めて， ストレスの生命科学は, これからの重要な研究課題の一つとなるであろう。 